\title{
NR1D2 wt Allele
}

National Cancer Institute

\section{Source}

National Cancer Institute. NR1D2 wt Allele. NCI Thesaurus. Code C101742.

Human NR1D2 wild-type allele is located in the vicinity of 3p24.2 and is approximately 35 $\mathrm{kb}$ in length. This allele, which encodes nuclear receptor subfamily 1 group $D$ member 2 protein, plays a role in the regulation of gene expression. 